\title{
Regression models for the front grinding process on Grey Cast Iron block-engine
}

\author{
Modelos de regresión para el proceso de rectificado frontal \\ de un block motor de fundición gris
}

\author{
Cristian Pérez-Salinas ${ }^{1 *} \quad$ Roberto Valencia Nuñez ${ }^{1} \quad$ Oscar Analuiza Maiza ${ }^{1}$ \\ Luis Fiallos Zamora ${ }^{1} \quad$ Jorge Paredes Zumbana ${ }^{2}$ \\ Recibido 07 de abril de 2018, aceptado 28 de julio de 2018 \\ Received: April 07, $2018 \quad$ Accepted: July 28, 2018
}

\begin{abstract}
This document describes the obtaining of different regression models for the surface roughness and wear parameter in abrasive wheels Alumina (Al2O3) and silicon carbide $(\mathrm{CSi})$ under the influence of cutting parameters in the frontal grinding process. The methodology used in the present study is based on the use of an experimental design (DOE) using two input variables (factors) feed rate and cut depth at three levels and a categorical variable tool at two levels. The methods used to obtain models were linear regression, multiple linear regression and logistic regression. The findings show that the type of tool and the speed of advance, have greater correlation with surface quality and wear respectively. All the models establish a significant incidence of these factors on the response variables with a confidence level of $95 \%$. The results of the test show that with the use of a carbide tool, a better surface quality can be obtained with the lowest wear parameter. Finally, an SEM test showed the best surface topography obtained with the carbide tool compared to the alumina tool.
\end{abstract}

Keywords: Regression models, grinding, wear parameter, surface roughness, cutting parameter.

\section{RESUMEN}

El presente documento describe la obtención de distintos modelos de regresión para la rugosidad superficial y parámetro de desgaste en muelas abrasivas Alúmina (Al2O3) y carburo de silicio (CSi) bajo la influencia de parámetros de corte en el proceso de rectificado frontal. La metodología utilizada en el presente estudio se basa en el uso de un diseño experimental (DOE) utilizando dos variables de entrada (factores) velocidad de avance y profundidad de corte a tres niveles y una variable categórica herramienta a dos niveles. Los métodos utilizados para la obtención de modelos fueron una regresión lineal, regresión lineal múltiple y regresión logística. Los hallazgos muestran que el tipo de herramienta y la velocidad de avance, tienen mayor correlación con la calidad superficial y el desgaste respectivamente. Todos los modelos establecen la incidencia significativa de estos factores sobre las variables de respuesta con un nivel de confianza del 95\%. Los resultados finales del ensayo muestran que con el uso de una herramienta de carburo se puede obtener una mejor calidad superficial con el menor parámetro de desgaste. Finalmente, un ensayo SEM permitió evidenciar la mejor topografía superficial obtenida con la herramienta de carburo en comparación con la herramienta de alúmina.

Palabras clave: Modelos de regresión, rectificado, parámetro de desgaste, rugosidad superficial, parámetros de corte.

\footnotetext{
1 Universidad Técnica de Ambato. Facultad de Ingeniería Civil y Mecánica. Ambato, Ecuador.

E-mail: cf.perez@uta.edu.ec; edisonrvalencia@uta.edu.ec; oi.analuiza@uta.edu.ec; chinofabiano10@ gmail.com

2 Departamento técnico. Energías del Agro San Juan Playas. Ecuador. E-mail: alexandro96@gmail.com

* Autor de correspondencia: cf.perez@uta.edu.ec
} 


\section{INTRODUCTION}

Grinding is the machining process that uses hard abrasive particles as a cutting medium. Grinding belongs to abrasive processes within the classification of manufacturing processes, specifically belongs to processes that use agglomerated abrasive particles. The geometric shape obtained is called "grinding wheel" which can vary its profile according to the final use [1]. Other uses of abrasive processes are used for cutting, polishing, grinding and sharpening tools; The latter is feasible due to the greater hardness that abrasive particles have compared to the materials used to make tools such as high-speed steel and hard metal [2-3].

Grinding is considered as a finishing machining process in the production of components that require a smooth surface and excellent tolerance. Nowadays, the grinding process supposes between $20-25 \%$ of the total manufacturing cost between the different processes found in the industry [1, 4-5]. The front grinding of engine blocks is an important economic activity in many countries where the population of used vehicles is considerable. It is important to indicate that the vehicular population in the world increases steadily, and the trend is the reduction of automotive waste, as well as increasing its useful life [6-7]. The repair of engines is an activity that contributes positively to the economy of small businesses as well as the development of technological knowledge. Repair techniques have evolved in parallel with the advancement of machining technologies [8-9].

In the grinding, the life of the wheels and cycle times cannot be determined in a direct way, as for example the use of standard tables [10]. The wear of the grain is relevant in the process, since its appearance causes a lot of unwanted effects [11]. Accordingly, grinding has been the subject of extensive research, especially during the last 50 years; due to the large number of variables involved in the process [12]. Recently, studies have been developed on abrasive wear, techniques such as microscopic observations on the wheel and high-speed instant microphotographs have been used [13]; However, they provide little practical process information about the influence of cutting parameters such as: cutting speed, feed speed, depth of cut, type of coolant; in the machining results [14].
Considering abrasive processes as "applied science" [15], it can be said that wear is a function of time; that is, it is affected by factors such as: the construction of the wheel, the operating parameters, the material of the work piece and the cooling [16]. The quantification of wear is very complex because it involves, in addition to the cutting parameters, phenomena such as friction that appears due to factors such as the relative contact area and the combinatorial effect of the speed and the cutting pressure [17-18]. Therefore, the parameter used for the measurement of grain wear is the corresponding loss percentage on the flat faces of the wheel with respect to the apparent area of its surface [19].

When analyzing the process as a tribo-chemical wear caused by the aggressive conditions of contact pressure and cutting speed, this generates high temperatures causing adhesion and abrasion phenomena, consequently the appearance of a third body becomes effective. Authors like [1, 17, 20] have carried out studies in which they analyze the composition of the third body after contact between Alumina and Steel, finding differences due to contact conditions. Another problem is the quantification of the wear of the wheel due to the random surface of the wheels and the size of the abrasive grain, therefore, there is no predominant methodology. There are studies that the measurements are carried out during the grinding process and others once the grinding has been completed using the extraction technique of the topography and profilometers respectively $[1,4,13,16,21]$.

Many studies have used various experimental techniques and statistics to obtain useful information when executing manufacturing processes [22-24]. The experimental designs allow to direct the correct execution in this case of machining tests. In machining phenomena different types of regression are adjusted to each type of process, so it is necessary to verify appropriate adjustment values [25-27].

The trend in the latest research on production and manufacturing of products refers to the search for logistic and probabilistic regression models to predict the best machining conditions in terms of quality, cost and time [25, 28-30]. In processes where there are limited number of levels for the factors in the experimental designs, the logistic regression can be useful to discretize the results and obtain adequate 
solutions when selecting parameters such as tool type and levels of the cutting parameters [31-32]. In view of the roughness of the elements and the wear of tools are closely related, and the need to obtain excellent surface qualities in production; it is necessary to obtain statistical models of these variables in the process of grinding on blocks of gray cast iron. It is also necessary to establish comparisons between tools commonly used in the process, since in operations of maintenance and repair of engines it is imperative to have technical recommendations on the controllable cutting parameters that provide an acceptable level of surface quality for an adequate performance of said machines.

\section{METHODOLOGICAL PROCESSES}

\section{Materials and instrumentation}

Two types of wheels were used for the experimental process of frontal grinding. The first was a silicon carbide abrasive wheel (series: 2C54-J6V) of dimensions $125 \times 60 \times 15 \mathrm{~mm}$, and a second aluminum oxide wheel "Alumina or corundum" (1A30-K7VBE) of dimensions $110 \times 60 \times 20 \mathrm{~mm}$. The machining process was carried out on a gray cast iron engine block with a chemical composition summarized in Table 1, the result of a spectrometric test.

Table 1. Average values of the chemical composition of the gray cast iron engine block.

\begin{tabular}{|c|c|c|c|c|c|c|}
\hline Components & $\begin{array}{c}\mathrm{C} \\
(\boldsymbol{\%})\end{array}$ & $\begin{array}{c}\mathbf{S i} \\
(\boldsymbol{\%})\end{array}$ & $\begin{array}{c}\mathbf{M n} \\
(\boldsymbol{\%})\end{array}$ & $\begin{array}{c}\mathbf{C r} \\
(\boldsymbol{\%})\end{array}$ & $\begin{array}{c}\mathbf{C u} \\
(\boldsymbol{\%})\end{array}$ & $\begin{array}{c}\mathbf{F e} \\
(\boldsymbol{\%})\end{array}$ \\
\hline Average & 3.22 & 1.86 & 0.60 & 0.03 & 0.01 & 94.1 \\
\hline
\end{tabular}

Through of a metallographic test, the gray cast iron possesses $22.7 \%$ and $77.3 \%$ of graphite and cementite respectively; In addition, by an image obtained by electron microscopy, the laminar form of the graphite in the base material is evidenced in Figure 1.

The tests were carried out on a flat surface front grinding machine series: 3M735x1500 of Chinese origin with a feed speed capacity of 0-20000 mm/ min, a cutting speed of 0 to $30 \mathrm{~m} / \mathrm{sec}$ and a cutting depth of 0 to $4 \mathrm{~mm}$. The experimental arrangement of the motor block on the grinding machine is shown in Figure 2.

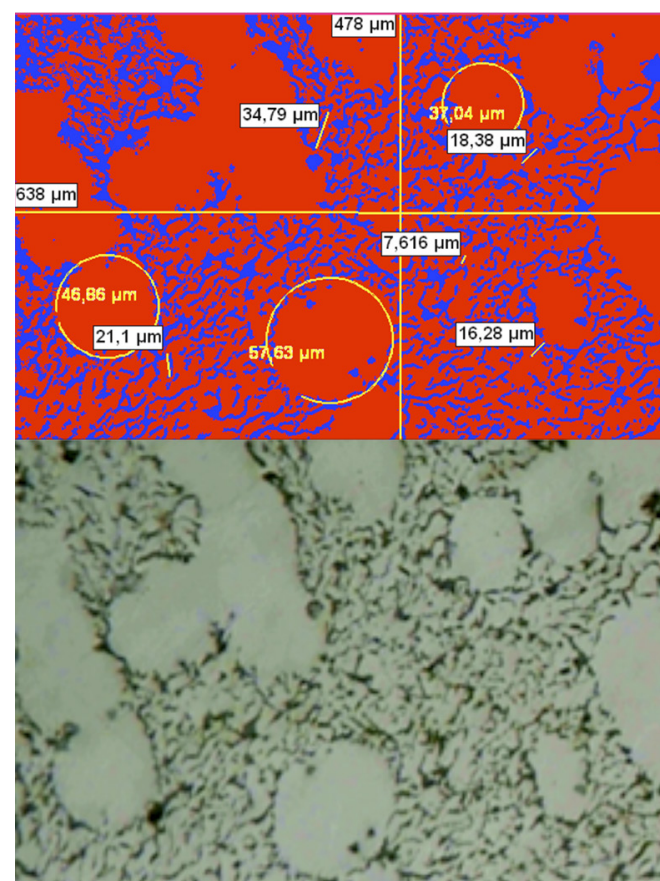

Figure 1. Gray Cast Iron Metallography.

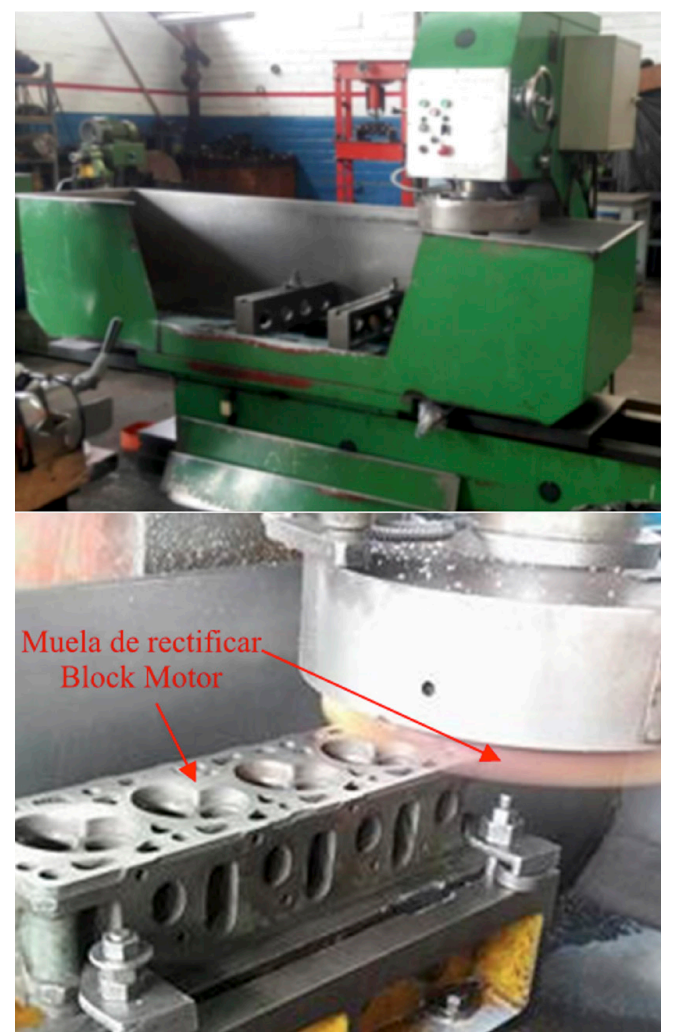

Figure 2. Front grinding machine and experimental machining arrangement. 
To measure the values of the surface roughness Ra, a SJ-210 Mitutoyo rugosimeter with $1 \mathrm{~cm}$ probe displacement was used. To evaluate the topography of surface wear in both the motor block and the cutting tool, the scanning microscope SEM "Scanning Electron Microscope VEGA3 SEM" was used.

\section{Test methodology}

For the analysis of the surface quality and wear of the tools, an experimental DOE design was generated with two quantitative variables and a categorical one. The continuous variables are a function of the cutting parameters such as the depth of pass (Ap), the speed of advance of the work table (Vf) each of them at three levels; and the use of two types of tools $(\mathrm{H})$. The experimental generation (Table 2) and its analysis were carried out using Minitab software version 18 .

Table 2. Experimental design.

\begin{tabular}{|l|c|c|c|}
\hline \multicolumn{1}{|c|}{ Cutting parameters } & Low & Medium & High \\
\hline Depth of cutting, $A p(\mu p l g)$ & 1 & 1.5 & 3 \\
\hline Feed velocity, $V f(\mathrm{~mm} / \mathrm{min})$ & 13000 & 18000 & 20000 \\
\hline Tools, $H$ & A & C & - \\
\hline
\end{tabular}

In this study, 18 experiments were carried out as result of all possible combinations of the input variables with two replicates. For each test, 5 passes were made on the surface of the motor block, to then perform the roughness measurements (Ra) with the Mitutoyo SJ-210 rugosimeter in different surface areas. Then the wear parameter $(\mathrm{G})$ of dimensionless character was determined according to equation (1). Where, $\left(\mathrm{V}_{\mathrm{w}}\right)$ is the volume of the material removed from the head in $\mathrm{mm} 3$ and (Vs) is the volume of the wheel worn in $\mathrm{mm} 3$.

$$
G=\frac{V_{w}}{V_{s}}
$$

\section{Logistic regression analysis}

To obtain a prediction model to obtain an excellent level of surface roughness with a minimum wear rate of the tool, we used a logistic regression model that discretizes the experimental results at categorical levels. For the case of roughness, the levels are "Excellent" and "Good" respectively, for the case of wear rate of the tool the levels are "greater wear" and "less wear" respectively.
Previously, Spearman's statistical correlation method was applied to find relationships among the 5 variables ( 3 factors and 2 outputs), where the correlation coefficients are in the range of -1 to 1 . Table 3 shows the meaning of said values. equation 2 allows to establish the relationships between variables.

$$
r=\frac{\sum x y}{\sqrt{\left(\sum x^{2}\right)\left(\sum y^{2}\right)}}
$$

Once determined the highest correlations between factors and output variables $(\mathrm{Ra})$ and $(\mathrm{G})$ respectively, a linear regression analysis was performed to obtain a predictor model and graph the trend between them.

Table 3. Values for the degree of correlation between variables.

\begin{tabular}{|l|l|}
\hline \multicolumn{1}{|c|}{ Value } & \multicolumn{1}{c|}{ Meaning } \\
\hline-1 & Large and perfect negative correlation \\
\hline$-0,9$ a $-0,99$ & Very high negative correlation \\
\hline$-0,7$ a $-0,89$ & High negative correlation \\
\hline$-0,4$ a $-0,69$ & Moderate negative correlation \\
\hline$-0,2$ a $-0,39$ & Low negative correlation \\
\hline$-0,01$ a $-0,19$ & Very low negative correlation \\
\hline 0 & Null correlation \\
\hline 0,01 a 0,19 & Very low positive correlation \\
\hline 0,2 a 0,39 & Low positive correlation \\
\hline 0,4 a 0,69 & Moderate positive correlation \\
\hline 0,7 a 0,89 & High positive correlation \\
\hline 0,9 a 0,99 & Very high positive correlation \\
\hline 1 & Positive and large positive correlation \\
\hline
\end{tabular}

Finally, a logistic prediction model was made with the intention of obtaining an excellent level of surface roughness with a minimum wear rate of the tool. For this purpose, it was necessary to discretize the rugosity and wear values obtained in experimental analysis at categorical levels. The interpretation of the logistic model and its probability are governed by equations (3) and (4) respectively. Where $\beta$, represents the coefficients of the model and $x$ the predictive factors for the output variable $\mathrm{Z}_{\mathrm{t}}$.

$$
\begin{gathered}
Z_{t}=\beta_{0}+\beta_{1} x_{1}+\beta_{2} x_{2}+\beta_{3} x_{3}+\ldots+\beta_{n} x_{n} \\
P t=\frac{e^{Z_{t}}}{1+e^{Z_{t}}}
\end{gathered}
$$


For the case of roughness, the levels are "Excellent" and "Good" respectively, in the same way, for the case of wear rate of the tool, the levels are "greater wear" and "less wear". A value of one " 1 " is assigned for those results lower than the comparative term and zero " 0 " for those higher values as evidenced by the values "Ra_dis" and "G_dis" (Table 5), with the premise that both the superficial roughness of an element such as the wear of a grinding wheel is considered to have a positive impact when its values are as low as possible; otherwise, their performance and quality are negative when their values are high.

The dichotomous characterization of the variable (Ra) was based on the values recommended by ISO 1302: 2002 [33] for the grinding process, where the roughness values are "excellent" if they are below $1.6 \mu \mathrm{m}$; otherwise, they will be "good" because the results are within acceptable values according to that norm. On the other hand, as there is no normative parameter to analyze $(\mathrm{G})$; the following criterion was established, "the less wear is greater the durability of the tool", for it proceeded to calculate the descriptive statistics, then proceeded to calculate the point of balance of the data to determine the critical point of wear (Table 4, Figure 3).

Table 4. Statistical values of measures of central.

\begin{tabular}{|c|c|c|c|c|c|}
\hline Min. & 1st Qu. & Median & Mean & 3rd Qu. & Max. \\
\hline 90.2 & 19.74 & 28.58 & 31.2 & 39.11 & 69.19 \\
\hline
\end{tabular}

With the normality test of Shapiro Wilk, it was found that the data are NOT distributed in a normal way, consequently the critical point would be: the mean $=$ median $=$ fashion. For this reason, the lowest value among them was taken, which corresponds to the median: 28.58. With this value, we say that the data smaller than 28.58 is considered a "Less wear" and a greater durability of the tool. Otherwise there is a "greater wear" and less durability of the tool. Thus, the coding used was: $1=$ Less wear; 0 $=$ Greater wear.

\section{RESULTS}

\section{Experimental result}

The obtained values of roughness $(\mathrm{Ra})$ and wear $(\mathrm{G})$ and their discretization in dichotomous variables

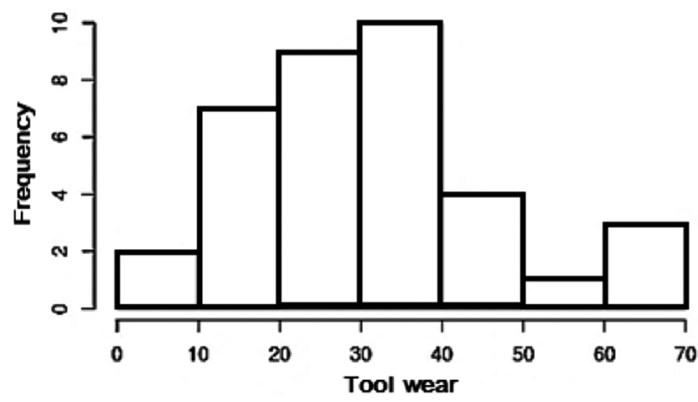

Figure 3. Histogram of the experimental data of wear $(\mathrm{G})$.

(Ra_di and G_di) respectively, are presented in Table 5.

Figures 4 and 5 show the graphs of main effects of adjusted means for the roughness (Ra) and wear (G) caused by the cutting parameters and type of tool. From the experimental analysis, can be seen that the type of tool has a considerable effect on the surface roughness. On the other hand, the speed of advance shows a significant effect on the wear rate of the tools. These factors show a great effect in the dependent variables since there is a wide range of variation in the values as shown in the mentioned figures.

Specifically, working with an advance speed of $20,000 \mathrm{~mm} / \mathrm{min}$ will give an average roughness (Ra) of $1,86627 \mu \mathrm{m}$, while with an advance speed of $13,000 \mathrm{~mm} / \mathrm{min}$ you will obtain an average roughness (Ra) value of $2.01055 \mu \mathrm{m}$. If you work with a depth of cut of 3.0 thousandths of an inch $(0.0762 \mathrm{~mm})$ you will obtain a roughness $(\mathrm{Ra})$ average of $1.81898 \mu \mathrm{m}$, while with a depth of cut 1.5 thousandths of inches $(0,0381 \mathrm{~mm})$ a mean roughness $(\mathrm{Ra})$ of $2.07012 \mu \mathrm{m}$ will be obtained. Finally, if you work with a silicon carbide tool you will obtain the lowest average roughness (Ra) with a value of $1.53608 \mu \mathrm{m}$, while with the aluminum oxide tool you will obtain the highest average roughness (Ra) with a value of $2.33443 \mu \mathrm{m}$.

In reference, to the variable wear $(\mathrm{G})$, it is determined that if you work with a feed rate of $20,000 \mathrm{~mm} /$ min you will obtain an average wear parameter (G) of 18,0276, while with an advance speed of $13,000 \mathrm{~mm} / \mathrm{min}$ an average wear parameter $(\mathrm{G})$ of 42,345 will be obtained. 
Table 5. Result of roughness (Ra) and wear $(\mathrm{G})$ and its discretization in dichotomous variables (Ra_di and $G_{-}$di) respectively.

\begin{tabular}{|c|c|c|c|c|c|c|c|}
\hline $\mathbf{N}^{\mathbf{0}}$ & $\mathbf{H}$ & $\mathbf{V f}(\mathbf{m m} / \mathbf{m i n})$ & $\mathbf{A p}(\mathbf{m m})$ & $\mathbf{R a}(\boldsymbol{\mu p l g})$ & $\mathbf{G}$ & Ra_dis & G_dis \\
\hline 1 & 1 & 13000 & 1.0 & 2.5990 & 36.10000 & 0 & 0 \\
\hline 2 & 1 & 13000 & 1.5 & 1.6630 & 39.11000 & 0 & 0 \\
\hline 3 & 1 & 13000 & 3.0 & 1.5878 & 36.10000 & 1 & 0 \\
\hline 4 & 1 & 18000 & 1.0 & 1.2900 & 40.61000 & 1 & 0 \\
\hline 5 & 1 & 18000 & 1.5 & 1.2904 & 40.61057 & 1 & 0 \\
\hline 6 & 1 & 18000 & 3.0 & 1.4560 & 25.06800 & 1 & 1 \\
\hline 7 & 1 & 20000 & 1.0 & 1.8700 & 18.04900 & 0 & 1 \\
\hline 8 & 1 & 20000 & 1.5 & 2.0632 & 26.07000 & 0 & 1 \\
\hline 9 & 1 & 20000 & 3.0 & 1.2904 & 27.07000 & 1 & 1 \\
\hline 10 & 2 & 13000 & 1.0 & 2.2610 & 69.19000 & 0 & 0 \\
\hline 11 & 2 & 13000 & 1.5 & 2.7190 & 45.12000 & 0 & 0 \\
\hline 12 & 2 & 13000 & 3.0 & 2.2862 & 69.19000 & 0 & 0 \\
\hline 13 & 2 & 18000 & 1.0 & 1.5390 & 27.07000 & 1 & 1 \\
\hline 14 & 2 & 18000 & 1.5 & 2.2880 & 30.08000 & 0 & 0 \\
\hline 15 & 2 & 18000 & 3.0 & 2.4510 & 36.09830 & 0 & 0 \\
\hline 16 & 2 & 20000 & 1.0 & 1.9700 & 17.04640 & 0 & 1 \\
\hline 17 & 2 & 20000 & 1.5 & 2.6904 & 14.29000 & 0 & 1 \\
\hline 18 & 2 & 20000 & 3.0 & 2.5334 & 9.02000 & 0 & 1 \\
\hline 19 & 1 & 13000 & 1.0 & 1.1060 & 60.16000 & 1 & 0 \\
\hline 20 & 1 & 13000 & 1.5 & 1.0080 & 33.09000 & 1 & 0 \\
\hline 21 & 1 & 13000 & 3.0 & 1.0630 & 30.08000 & 1 & 0 \\
\hline 22 & 1 & 18000 & 1.0 & 1.3260 & 40.61000 & 1 & 0 \\
\hline 23 & 1 & 18000 & 1.5 & 2.3100 & 39.11000 & 0 & 0 \\
\hline 24 & 1 & 18000 & 3.0 & 1.4560 & 25.06800 & 1 & 1 \\
\hline 25 & 1 & 20000 & 1.0 & 1.8700 & 18.04900 & 0 & 1 \\
\hline 26 & 1 & 20000 & 1.5 & 1.1374 & 26.07000 & 1 & 1 \\
\hline 27 & 1 & 20000 & 3.0 & 1.2632 & 20.31000 & 1 & 1 \\
\hline 28 & 2 & 13000 & 1.0 & 2.5990 & 22.56000 & 0 & 1 \\
\hline 29 & 2 & 13000 & 1.5 & 2.4780 & 57.16000 & 0 & 0 \\
\hline 30 & 2 & 13000 & 3.0 & 2.4756 & 11.28000 & 0 & 1 \\
\hline 31 & 2 & 18000 & 1.0 & 2.6000 & 27.07000 & 0 & 1 \\
\hline 32 & 2 & 18000 & 1.5 & 2.6900 & 30.08000 & 0 & 0 \\
\hline 33 & 2 & 18000 & 3.0 & 2.4510 & 36.09830 & 0 & 0 \\
\hline 34 & 2 & 20000 & 1.0 & 1.9700 & 17.05000 & 0 & 1 \\
\hline 35 & 2 & 20000 & 1.5 & 2.2230 & 14.29000 & 0 & 1 \\
\hline 36 & 2 & 20000 & 3.0 & 1.5140 & 9.02000 & 1 & 1 \\
\hline & & & & & & & \\
\hline
\end{tabular}

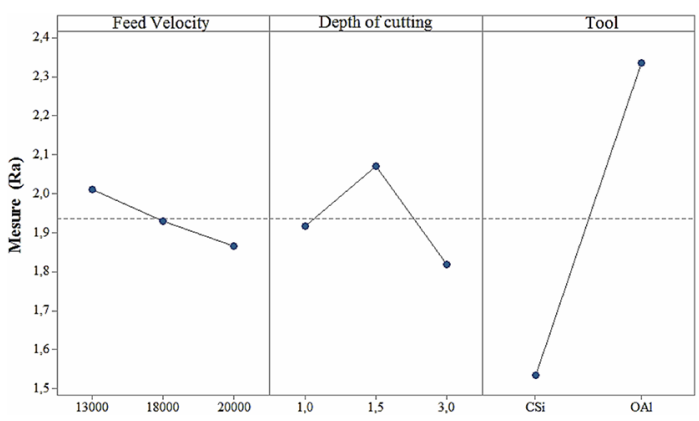

Figure 4. Graph of main effects for roughness (Ra).

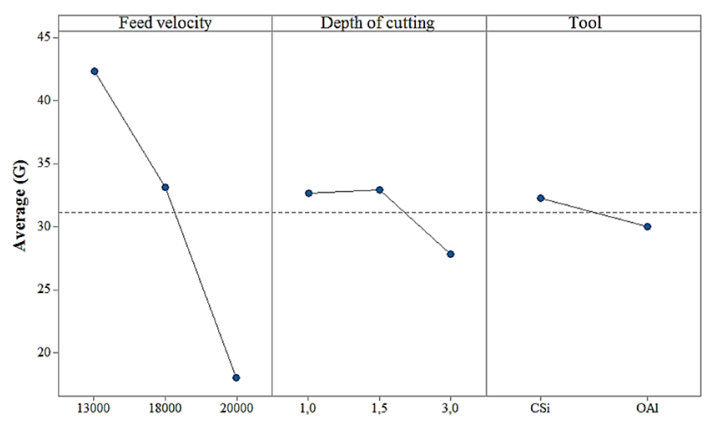

Figure 5. Graph of main effects for wear $(\mathrm{G})$. 
If you work with a depth of cut of 3.0 thousandths of an inch $(0.0762 \mathrm{~mm})$ you will get an average wear $(G)$ of 27.8669 , while with a depth of cut of 1.5 thousandths of an inch $(0,0381 \mathrm{~mm})$ a mean wear $(G)$ of 32.9234 will be obtained. Finally, if you work with a silicon carbide tool you will get the highest average wear $(\mathrm{G})$ with a value of 32.2964 , while with the aluminum oxide tool you will get a lower average wear $(\mathrm{G})$ with a value of 30.0394 .

\section{Spearman correlation result}

To determine the degree of association of variables, the application of the non-parametric Spearman correlation test was justified because the variables were transformed to an ordinal measurement level. According to Table 6, any of the 2 upper or lower diagonals can be interpreted. It is observed that the tool and the roughness have a high positive correlation (0.70). Meanwhile, there is a moderate inverse or negative correlation between the feed speed and tool wear $(-0.68)$, according to the interpretation of Table 3.

Table 6. Analysis of Spearman correlations among the 5 process variables.

\begin{tabular}{|l|r|c|r|r|r|}
\cline { 2 - 6 } \multicolumn{1}{c|}{} & Tool & $\begin{array}{c}\text { Feed } \\
\text { velocity }\end{array}$ & $\begin{array}{c}\text { Depth } \\
\text { cutting }\end{array}$ & Ra & G \\
\hline Tool & 1.00 & 0.00 & 0.00 & 0.70 & -0.20 \\
\hline Feed velocity & 0.00 & 1.00 & 0.00 & -0.10 & -0.68 \\
\hline Depth cutting & 0.00 & 0.00 & 1.00 & -0.08 & -0.14 \\
\hline Ra & 0.69 & -0.10 & -0.08 & 1.00 & -0.07 \\
\hline G & -0.20 & -0.68 & -0.14 & -0.07 & 1.00 \\
\hline
\end{tabular}

Linear regression model with higher correlation variables.

The model is adjusted with a coefficient of determination ( $\mathrm{R}$ squared) of 0.47 and 0.37 for the prediction "Roughness-Tool" and "Wear-feed velocity" respectively. Although the coefficients of determination are low, the intention was to show the relationship between variables and their behaviors. Figure 6 shows the trends of the models mentioned and Table 7 shows their level of significance.

Therefore, the following predictive equations (5) and (6) are obtained for roughness (Ra) and wear parameter $(\mathrm{G})$ respectively:

$$
y=\beta_{0}+\beta_{1} x
$$

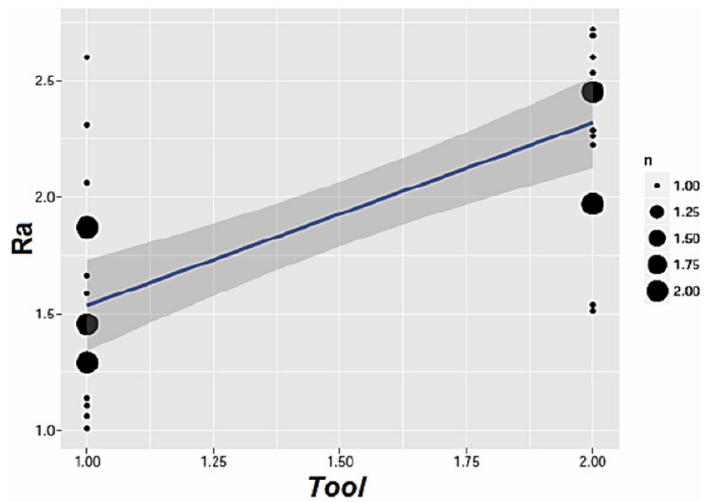

(a)

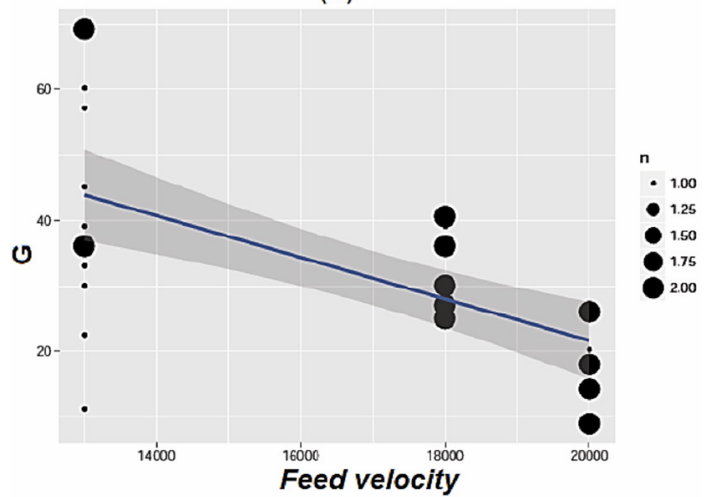

(b)

Figure 6. Linear regression model, (a) between the roughness and the tool, (b) between the speed of advance and wear of the tool.

Table 7. Linear regression analysis between correlated variables.

\begin{tabular}{|c|c|c|c|c|}
\hline & $\begin{array}{c}\text { Estimate } \\
\text { Std. }\end{array}$ & $\begin{array}{c}\text { Error } \\
\mathbf{t}\end{array}$ & value & $\underset{(>|\mathbf{t}|)}{\operatorname{Pr}}$ \\
\hline \multicolumn{5}{|c|}{ Roughness (Ra) } \\
\hline (Intercept) & 0.7533 & 0.2148 & 3.508 & $0.00129 * *$ \\
\hline Tool & 0.7827 & 0.1358 & 5.763 & $1.75 \mathrm{e}-06^{* * *}$ \\
\hline \multicolumn{5}{|c|}{ Wear $(G)$} \\
\hline \begin{tabular}{|l|} 
(Intercept) \\
\end{tabular} & 20785.5 & 911.0 & 22.816 & $<2 \mathrm{e}-16^{* * *}$ \\
\hline Feed velocity & -121.3 & 26.3 & -4.614 & $5.41 \mathrm{e}-05^{* * * *}$ \\
\hline
\end{tabular}

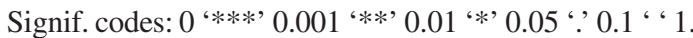

$$
\begin{gathered}
R a=07533+0.7827 H \\
G=20785.5-121.3827 V f
\end{gathered}
$$

\section{Multiple linear regression model}

The factor Tool, has greater incidence on the superficial quality of the mechanized (Ra) and the 
factor Feed velocity, is a highly significant on the parameter of wear of the tool (Table 8).

From the multiple regression analysis, predictive models for roughness and wear parameters are obtained (equations (7) and (8), respectively).

$$
\begin{aligned}
& R a=1.162-3.239 H-0.00001618 V f-0.026 A p \\
& G=93.3415-2.2012 H-0.00317 V f-2.674134 A p
\end{aligned}
$$

\section{Logistic regression model}

The results of the logistic regression analysis for the roughness and wear parameter are shown in Table 9.

In the logistic regression model, the variable "Tool" has a higher incidence with the model to have an excellent roughness probability, for which it is concluded that when Tool 1 is used, there is a high probability that the value of the Roughness is less than 1.6. Therefore, we obtain equation (9) and (10) predictors for the logistic model and the probability of the model respectively.

$$
\begin{gathered}
Z t_{(R a)}=1.407-3.239 H+0.00005 V f+1.041 \mathrm{Ap} \\
P t_{(R a)}=\frac{e^{1.407-3.239 H+0.00005 V f+1.041 A p}}{1+e^{1.407-3.239 H+0.00005 V f+1.041 A p}}
\end{gathered}
$$

The variable Feed velocity have a great affectation in this model so that the probability of having a minimum wear is high; for this reason, it is concluded that, to have a minimum wear the speed of advance must be $20000 \mathrm{~m} / \mathrm{min}$. Therefore, it is obtaining the predictor equations (11) and (12) for the logistic model and the model probability, respectively.

$$
Z t_{(G)}=-11.1182+0.7186 H+0.00056 V f+0.2516 A p
$$

\begin{tabular}{|c|c|c|c|c|}
\hline & Estimate Std. & Error t & value & $\operatorname{Pr}(>|t|)$ \\
\hline \multicolumn{5}{|c|}{ Roughness $(R a)$} \\
\hline (Intercept) & $1.407 \mathrm{e}+00$ & $2.863 e+00$ & 0.491 & 0.62315 \\
\hline Tool & $-3.239 e+00$ & $1.084 \mathrm{e}+00$ & -2.987 & $0.00282 * *$ \\
\hline Feed velocity & $4.495 \mathrm{e}-05$ & $1.504 \mathrm{e}-04$ & 0.299 & 0.76509 \\
\hline Depth of cutting & $1.041 \mathrm{e}+00$ & $5.966 \mathrm{e}-01$ & 1.745 & 0.08097 \\
\hline \multicolumn{5}{|c|}{$\operatorname{Wear}(G)$} \\
\hline (Intercept) & $-1.112 \mathrm{e}+01$ & $3.903 e+00$ & -2.849 & $0.00439 * *$ \\
\hline Tool & $7.186 \mathrm{e}-01$ & $8.640 \mathrm{e}-01$ & 0.832 & 0.40557 \\
\hline Feed velocity & $5.548 \mathrm{e}-04$ & $1.822 \mathrm{e}-04$ & 3.045 & $0.00233 * *$ \\
\hline Depth of cutting & $2.516 \mathrm{e}-01$ & $5.074 \mathrm{e}-01$ & 0.496 & 0.61993 \\
\hline
\end{tabular}

Table 8. Multiple linear regression analysis for Roughness (Ra) and Wear (G).

\begin{tabular}{|l|c|c|c|c|}
\cline { 2 - 5 } \multicolumn{1}{c|}{} & Estimate Std. & Error t & value & Pr $(>|\mathbf{t}|)$ \\
\hline (Intercept) & $1.162 \mathrm{e}+00$ & $4.755 \mathrm{e}-01$ & 2.443 & $0.0203 *$ \\
\hline Tool & $7.827 \mathrm{e}-01$ & $1.373 \mathrm{e}-01$ & 5.702 & $2.57 \mathrm{e}-06^{* * *}$ \\
\hline Feed velocity & $-1.618 \mathrm{e}-05$ & $2.331 \mathrm{e}-05$ & -0.694 & 0.4926 \\
\hline Depth of cutting & $-7.260 \mathrm{e}-02$ & $8.076 \mathrm{e}-02$ & -0.899 & 0.3754 \\
\hline \multicolumn{5}{|c|}{ Wear $(G)$} \\
\hline (Intercept) & 93.3415588 & 14.1237209 & 6.609 & $1.89 \mathrm{e}-07 * * *$ \\
\hline Tool & -2.2011985 & 4.0771670 & -0.540 & 0.593 \\
\hline Feed velocity & -0.0031730 & 0.0006925 & -4.582 & $6.66 \mathrm{e}-05 * * *$ \\
\hline Depth of cutting & -2.6741343 & 2.3987947 & -1.115 & 0.273 \\
\hline
\end{tabular}

Signif. codes: 0 ‘***’ 0.001 ‘**’ 0.01 '*’ 0.05 '? 0.1 ' ‘ 1 .

Table 9. Logistic regression analysis for Roughness (Ra) and Wear (G).

Signif. codes: 0 ‘***’ 0.001 ‘**’ 0.01 '*’ 0.05 '? 0.1 ' ‘ 1 . 


$$
P t_{(G)}=\frac{e^{-11.1182+0.7186 H+0.000556 V f+0.2516 A p}}{1+e^{-11.1182+0.7186 H+0.000556 V f+0.2516 A p}}
$$

\section{Scanning microscopy SEM}

By means of EDM tests, the micro surface structure of both the rectified motor block and the used wheels were obtained. For this purpose, we worked on different increases with different energy levels (Figure 7 and 8). The images were obtained by

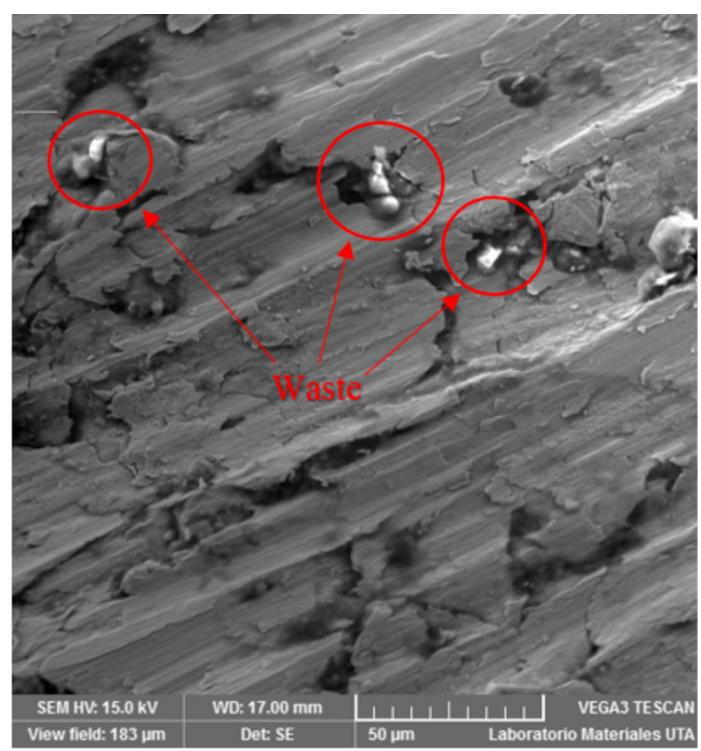

(a)

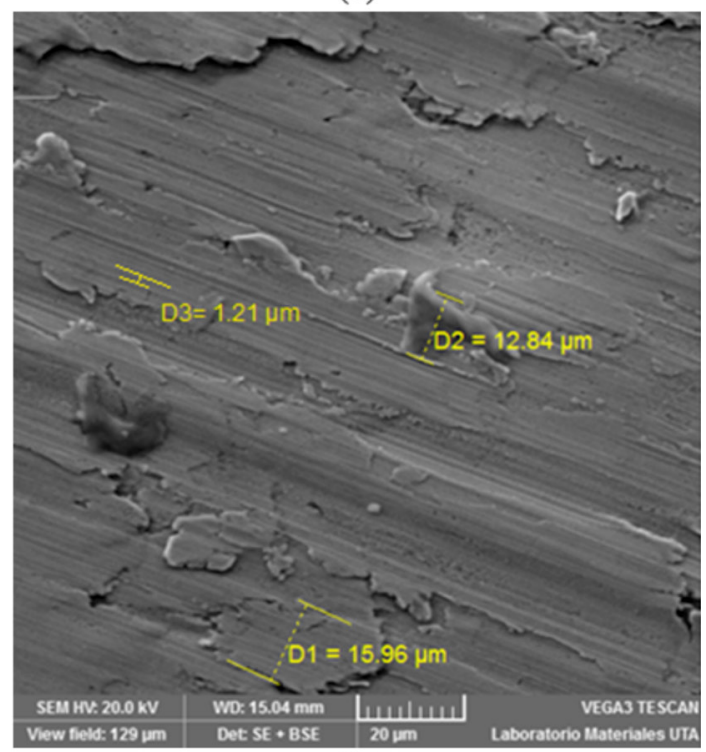

(b)

Figure 7. SEM scanning microscopy analysis of gray cast iron block surface, (a) Waste tool, (b) Surface dimensions.

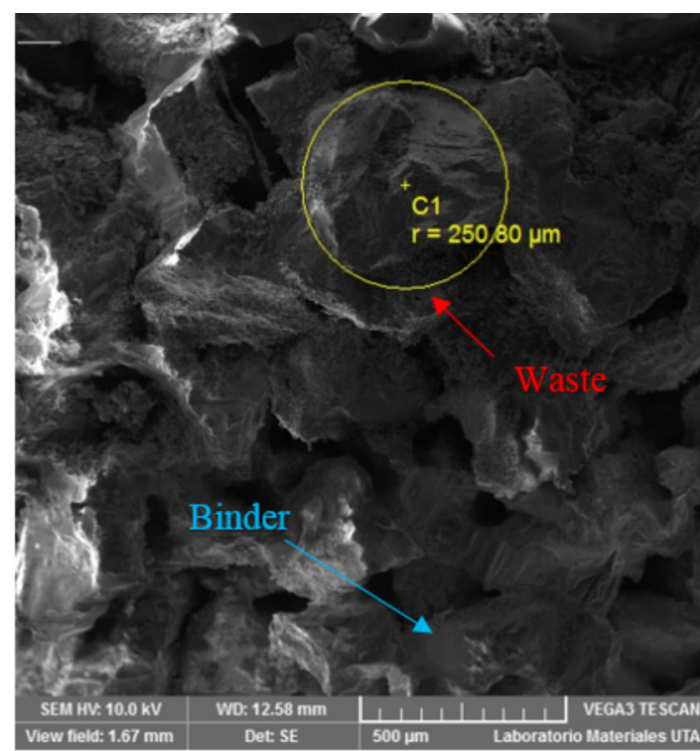

(a)

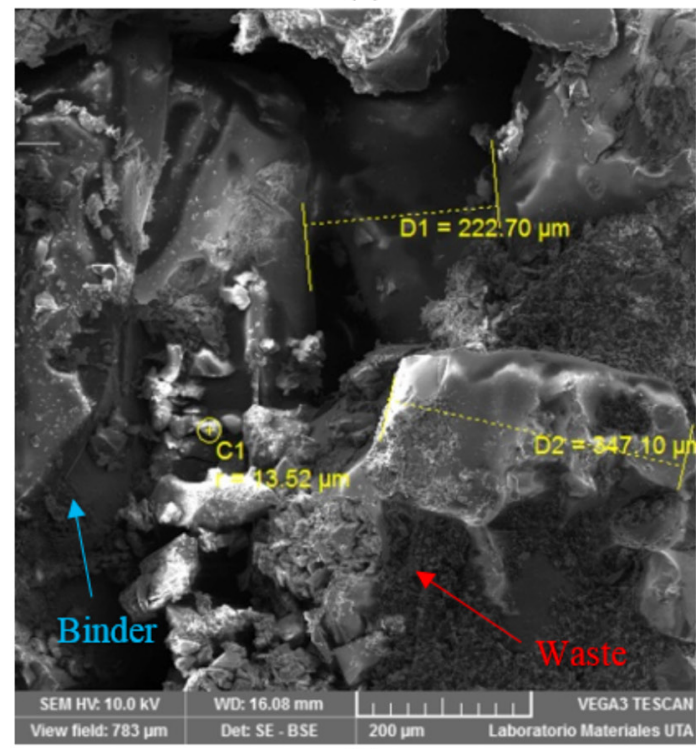

(b)

Figure 8. Analysis of SEM scanning microscopy of the surface of the tools, (a) Alumina stone, (b) Carbide stone.

retro-dispersed electrons and detector of secondary electrons according to the case.

From the photographs acquired, it is can see the topography of wear of both the tool and the machined material. In the case of Figure 7, corresponding to the machining topography of the block, deformation due to crushing of the tool and the appearance of abrasive 
particles on the surface are evident (Figure 7a); In addition, it is appreciating the machining direction with a measured roughness of $1.21 \mu \mathrm{m}$ as shown in Figure $7 b$. Finally, it is clearly seen that the machining surface with the Carbure tool leaves a better surface quality (Figure 7b). In this image, a clean surface with topographic uniformity is noted compared to the image of the Alumina tool (Figure 7a).

Figure 8 shows SEM images of the surfaces of the grinding tools. These images show the grain sizes, areas of accumulation of waste from the manufactured material. In addition, the distribution of the typical vitreous binder is distinguished for the case of the two types of tools that surround the abrasive grains. The sizes of said abrasives were measured between 222 to $250 \mu \mathrm{m}$ respectively, which are concordant to sizes specified in the literature for the two types of grinding stones [34-35]. Standard sizes for mediumsized abrasive wheels are between 212 to $600 \mu \mathrm{m}$.

\section{CONCLUSIONS}

According to Spearman test tool type and feel velocity, have higher correlation with surface quality and wear respectively, this result confirmed in Logistic multiple linear regression with a confidence level of $95 \%$.

The parameters of the grinding process that have little impact on the surface roughness is the feed velocity, but they have a great influence on the wear of the grinding wheels. On the contrary, the tool has great influence on surface quality but low incidence on wear. All these results agree from the analysis of the experimental design to the incidence results of the regression models performed.

In this study, the factor that does not affect any of the response variables is the depth of cutting, since their degree of incidence according to the models obtained are statistically low.

Using a carbide tool leaves a better surface quality with less wear compared to the tool alumina gives a lower surface quality with increased wear, part of this is evident in the SEM images obtained from the surface of engine block.

Aluminum oxide, also called corundum, is a natural stone. Silicon carbide is a mixture of sand, rock salt and coke, a form of carbon. These two abrasive materials are obtained at temperatures of 2000 to 2200 ${ }^{\circ} \mathrm{C}$. The hardness of the two types of grindstones and grain size were found in the same normative range but there are differences in the performance and quality at work. Being two tools that have a certain similarity, compared to the gray cast show different behaviors. The cause of the lower wear resistance of Alumina is its acrimony, this due to the volumetric composition of the grinding wheel; that is, the greater the proportion of aluminum oxide, the greater the hardness and acrimony of the wheel. In this case, the hardness of the wheel used was of the middle range; therefore, it will have a medium wear resistance. In addition, one of the characteristics of Alumina stones is that their grains self-sharpen and break off more easily compared to Silicon Carbide.

Logically a harder material should wear less than a soft material, but in the case of abrasive wheels the behavior depends largely on the material to be machined. Silicon carbide is harder and more brittle than aluminum oxide. Due to its brittleness, silicon carbide wears out faster than aluminum oxide when grinding soft materials. When manufacturing harder materials, aluminum oxide wears faster because it is softer than silicon carbide. Gray cast iron is generally referred to as a hard material; therefore, the silicon carbide wheel will wear less in accordance with the results obtained in this study. Finally, it is recommended for the grinding of gray cast iron engines, use a silicon carbide grinding wheel to obtain a higher surface quality with less wear of the cutting tool.

\section{ACKNOWLEDGMENT}

Recognition to the company "Rectificadora Fiallos" for its collaboration of its infrastructure for the execution of the experiment. To the materials laboratories of the UTA-FICM and UTA-DIDE for their total contribution to the research development.

\section{REFERENCIAS}

[1] S. Malkin and C. Guo. "Grinding technology: theory and application of machining with abrasives". Industrial Press Inc. Second Edition. New York. 2008. ISBN: 978-0-8311-3247-7.

[2] I. Inasaki, H. Tönshoff and T. Howes. "Abrasive machining in the future". CIRP 
Annals-Manufacturing Technology. Vol. 42, pp. 723-732, 1993. ISSN: 0007-8506. DOI: 10.1016/S0007-8506(07)62535-9.

[3] N.N. Tselesin. "Abrasive tool with contoured surface". ed.: Google Patents. US. 1993-03-02.

[4] E. Brinksmeier, J. Aurich, E. Govekar, C. Heinzel, H.-W. Hoffmeister and F. Klocke. "Advances in modeling and simulation of grinding processes". CIRP AnnalsManufacturing Technology. Vol. 55, pp. 667-696, 2006. ISSN: 0007-8506. DOI: 10.1016/j.cirp.2006.10.003.

[5] S. Philippon, G. Sutter and A. Molinari. "An experimental study of friction at high sliding velocities". Vol. 257, pp. 777-784. 2004. ISSN: 0043-1648. DOI: 10.1016/j. wear.2004.03.017.

[6] F.M. Andersen, H.V. Larsen and M. Skovgaard. "Projection of end-of-life vehicles. Development of a projection model and estimates of ELVs for 2005-2030". February 2008.

[7] M. Álvarez Medina. "Cambios en la industria automotriz frente a la globalización: el sector de autopartes en México". Contaduría y Administración. 2002. ISSN: 0186-1042.

[8] J. Guzmán. "Analisis económico del proyecto del rectificado y/o reconstrucción de motores". 2016. URL: http://ri.uaemex. $\mathrm{mx} / \mathrm{bitstream} / \mathrm{handle} / 20.500 .11799 / 58844 /$ TESIS \% 20JUAN\%20GUZMAN\% 20 SANCHEZ-split-merge.pdf?sequence $=3$.

[9] J.A. Becerra Villanueva. "Metodología para el estudio de las causas de rotura de cigüeñales en motores de combustión interna alternativos y compresores alternativos. Aplicación en un modelo de mantenimiento predictivo". 2007. URL: https://idus.us.es/ xmlui/handle/11441/15842.

[10] M. Hitchiner, E. Uhlmann, W.B. Rowe and I. Inasaki. "Handbook of Machining with Grinding Wheels". ed.: CRC Press, Taylor \& Francis Group. 2007. ISBN 1-57444-671-1.

[11] S. Malkin and N.H. Cook. "The wear of grinding wheels: part 1-attritious wear"'. Journal of Engineering for Industry. Vol. 93, pp. 11201128. 1971. DOI: doi:10.1115/1.3428051.

[12] N. Chiu and S. Malkin. "Computer simulation for cylindrical plunge grinding". CIRP Annals-Manufacturing Technology. Vol. 42, pp. 383-387. 1993. ISSN: 0007-8506. DOI: 10.1016/S0007-8506(07)62467-6.
[13] H. Tsuwa. "An investigation of grinding wheel cutting edges". Journal of Engineering for Industry. Vol. 86, pp. 371-382. 1964. DOI: 10.1115/1.3670568.

[14] M. Rahman and K. Kadirgama. "Material removal rate and surface roughness on grinding of ductile cast iron using minimum quantity lubrication". International Journal of Automotive and Mechanical Engineering. Vol. 11, pp. 2471. 2015. ISSN: 2229-8649. DOI: 10.15282/ijame.11.2015.27.0208.

[15] W. Zeng, Z. Li, Z. Pei and C. Treadwell. "Experimental observation of tool wear in rotary ultrasonic machining of advanced ceramics". International Journal of Machine Tools and Manufacture. Vol. 45, pp. 14681473. 2005. ISSN: 0890-6955. DOI: 10.1016/j.ijmachtools.2005.01.031.

[16] C. Cui, X. Xu, H. Huang, J. Hu, R. Ye and L. Zhou. "Extraction of the grains topography from grinding wheels". Measurement. Vol. 46, pp. 484-490. 2013. ISSN: 0263-2241. DOI: 10.1016/j.measurement.2012.08.005.

[17] A. Ravikiran and B.P. Bai. "High speed sliding of $\mathrm{A} 12 \mathrm{O} 3$ pins against an En-24 steel disc". Wear. Vol. 162, pp. 296304. 1993. ISSN: 0043-1648. DOI: 10.1016/0043-1648(93)90512-K.

[18] H. Yoshikawa and T. Sata. "Study on Wear of Grinding Wheels: 1-Bond Fracture in Grinding Wheels". Journal of Engineering for Industry. Vol. 85, pp. 39-42. 1963. DOI: 10.1115/1.3667580.

[19] E.V. Sánchez, M. S. Lozano and R.P. Orts. "Caracterización del desgaste de grano en el rectificado con muelas de alúmina monocristal". XXI Congreso Nacional de Ingeniería Mecánica: Libro de Artículos: Universidad Miguel Hernández. 2016.

[20] F. Klocke, R. Engelhorn, J. Mayer and T. Weirich. "Micro-analysis of the contact zone of tribologically loaded secondphase reinforced sol-gel-abrasives". CIRP Annals-Manufacturing Technology. Vol. 51, pp. 245-250. 2002. ISSN: 0007-8506. DOI: 10.1016/S0007-8506(07)61509-1.

[21] S. Lachance, A. Warkentin and R. Bauer. "Development of an automated system for measuring grinding wheel wear flats". Journal of Manufacturing Systems. Vol. 22, pp. 130. 2003. ISSN: 0278-6125. DOI: $10.1016 /$ S0278-6125(03)90010-0. 
[22] D. Niranjan, G. Shivashankar, K.S. Rao and R. Praveen. "Optimization of Cutting Process Parameters on AL6061 Using ANOVA and TAGUCHI Method". Materials Today: Proceedings. Vol. 4, pp. 10845-10849. 2017. ISSN: 2214-7853. DOI: $10.1016 / j$. matpr.2017.08.037.

[23] K. Palanikumar, L. Karunamoorthy and R. Karthikeyan. "Parametric optimization to minimise the surface roughness on the machining of GFRP composites". Journal of materials science and technology. Vol. 22, pp. 66-72. 2006. DOI: 10.4314/ijest.v6i1.6.

[24] P. Palanisamy, I. Rajendran and S. Shanmugasundaram. "Prediction of tool wear using regression and ANN models in end-milling operation". The International Journal of Advanced Manufacturing Technology. Vol. 37, pp. 29-41. April 01, 2008. ISSN: 0268-3768. DOI: $10.1007 /$ s00170-007-0948-5.

[25] T. Erdik and Z. Şen. "Prediction of tool wear using regression and ANN models in end-milling operation a critical review". The International Journal of Advanced Manufacturing Technology. Vol. 43, pp. 765766. 2009. ISSN: 0268-3768. DOI: $10.1007 /$ s00170-008-1758-0.

[26] T. Kivak. "Optimization of surface roughness and flank wear using the Taguchi method in milling of Hadfield steel with PVD and CVD coated inserts". Measurement. Vol. 50, pp. 19-28. 2014. ISSN: 0263-2241. DOI: 10.1016/j.measurement.2013.12.017.

[27] G.L. Rozza, R.G. da Silva and S.I.M.G. Müller. "Estudo comparativo do uso de redes neurais artificiais e regressão linear múltipla para a previsão da concentração cáustica em uma etapa do processo de fabricação de alumina/ Comparative study of the use of artificial neural networks and multiple linear regression for the prediction of the caustic concentration in one step of the alumina manufacturing process". Revista Produção Online. Vol. 15, pp. 948. 2015. ISSN 1676-1901. DOI: 10.14488/16761901.v15i3.1941.
[28] A. Carpinteri, A. Fernández-Canteli, G. Fortese, M. Muñiz-Calvente, C. Ronchei and D. Scorza. "Probabilistic failure assessment of Fibreglass composites". Composite Structures. Vol. 160, pp. 1163-1170. 2017. ISSN: 0263-8223. DOI: 10.1016/j. compstruct.2016.11.010.

[29] J. Lee, L. Liao, E. Lapira, J. Ni and L. Li. "Informatics platform for designing and deploying e-manufacturing systems", in Collaborative Design and Planning for Digital Manufacturing. ed: Springer. pp. 1-35. 2009. ISBN 978-1-84882-286-3. DOI: 10.1007/978-1-84882-287-0_1.

[30] J. Karandikar and T. Kurfess. "Cost optimization and experimental design in milling using surrogate models and value of information". Journal of Manufacturing Systems. Vol. 37, pp. 479-486. 2015. ISSN: 0278-6125. DOI: 10.1016/j.jmsy.2014.10.002.

[31] S. Sperandei. "Understanding logistic regression analysis". Biochemia Medica. Vol. 24, pp. 12-18. Fecha de consulta: Febrero de 2015.09/06/received.11/26/accepted 2014. DOI: 10.11613/BM.2014.003.

[32] H. Li, Y. Wang, P. Zhao, X. Zhang and P. Zhou. "Cutting tool operational reliability prediction based on acoustic emission and logistic regression model". Journal of Intelligent Manufacturing. Vol. 26, pp. 923931. 2015. ISSN 0956-5515. DOI: 10.1007/ s10845-014-0941-4.

[33] ISO 1302:2002. “Geometrical Product Specifications (GPS) - Indication of surface texture in technical product documentation".

[34] ATLANTIC. "Grinding wheels and honing stones, creative and dinamic". D.E.I.I. 14001:2004, Ed. URL: http://www.atlanticschleifscheiben.de/fileadmin/redaktion/ bilder/downloads/broschueren/spanish/ Grinding_wheels_Spanish_04.pdf.

[35] NORTON. "Diamond and cBN Superabrasives. Standard products catalog". Effective 2014. URL: https://www.nortonabrasives.com/ sites/sga.na.com/files/document/CatalogNortonSuperabrasives-8068-2014.pdf. 